\title{
The Use of Kerinci Greeting in Jujun Dialect
}

\author{
Vera Yudi Aditama ${ }^{1 *}$, Syahrul R ${ }^{2}$, Tressyalina ${ }^{3}$, Afnita ${ }^{4}$, and Amril Amir ${ }^{5}$ \\ Universitas Negeri Padang, Indonesia \\ *Corresponding author.Email: verayudi0906@gmail.
}

\begin{abstract}
This study aims to describe and explain the use of the Kerinci Jujun dialect. This study uses descriptive qualitative methods that do not use statistical formulas in the data processing. The data in this study are speech in the form of greetings from the Kerinci community in the village of Jujun, Jambi Province. Data collection techniques use talking methods using basic fishing techniques and using advanced speaking techniques. Data will be presented by the informant method. Researchers obtained 32 greetings in the Kerinci Jujun dialect. There are 27 general greeting words, 4 traditional greeting words, and 1 religious greeting words which are Kerinci Jujun dialects.
\end{abstract}

Keywords: Greetings, dialects, speech, regional languages

\section{INTRODUCTION}

The word greeting from the local language is often replaced by the greeting of Indonesian and foreign languages. Like the local language of Apiak which was replaced by Indonesian father or Abi foreign languages, and many more local language greetings were replaced by Indonesian and foreign languages. This research is very important in order to preserve and promote local languages so as not to erode eroded by other languages. If no research is conducted, the existing regional languages will be lost and also the loss of language wealth in Indonesia. Besides this research can also be a contribution to science, especially in the field of linguistics.

Greetings are words used to greet someone or the person they are speaking both verbally and in writing and greetings can vary according to the nature of the relationship between speakers. (Chaer, 2000, p.107; Sugono, 2014, p.1232; and Yule, 2006).

Kridalaksana (in Misnawati, 2017, p.19) there are nine types of greeting words in Indonesian, namely:

1. Pronouns. For example I, You, You, Him, We, They, and so on.

2. Self-name. For example the name of the person used for all speech actors.

3. The term kinship. For example Father, Mother, Brother, Uncle, Sister, and so on.

4. Title and Rank. For example Doctors, Teachers, Generals, Lecturers, and so on.

5. The form pe $+\mathrm{V}$ (verb) or the word doer. For example performers, singers, and so on.

6. Form my noun +. For example my umbrella, my love, my flowers and so on.

7. Facts about deixis or pointers, for example: there, this, that and so on.

8. Nouns (nouns) or objects For example lady, noble, master and so on.
9. Zero or zero. For example, people who say "want to market?", The word "I" is not mentioned, it should be "I want to go to the market". Although without my words, the sentence can be interpreted.

A lot of research has been done on greeting words. The study was conducted in regional languages. As Misnawati's research (2017) about Minangkabau language greetings and obtained three major categories of greetings, including (1) general greetings, (2) custom greetings, and (3) religious greetings. Sari (2017) also conducted research on Malay greetings in Riau. From the results of the study, it was found that there are Fifty-Five Malay greeting words sub dialect Parit Senggarang, Sungai Ungar Utara Village, North Kundur District, Karimun Regency, Riau Islands Province. Rusbiyantoro (2011) also conducted research with the title Use of Greetings in Kutai Malay. His research results are (1) eight forms of kinship greetings, (2) pronouns in greeting words, (3) forms of self-names, (4) forms of royal titles, (5) forms of zero, (6) forms of nicknames, and ( 7) plural meaningful greetings. Mafika Sari (2016) conducted research with the title Greetings in Kodomo's Story Children Naritai Papa To Otona This Naritai Boku by Haitani Kenjirou and obtained the findings of 10 greeting words.

From many of the results of other people's studies that researchers have read, there is not a single study of the greeting of the Jujun dialect. Therefore, researchers feel the need to conduct research on the greeting of Kerinci Jujun dialects. This research will focus on three things, namely: (1) general greetings (kinship and non-kinship greetings), (2) custom greetings, and (3) religious greetings (Misnawati, 2017: 20).

\section{METHODS}

This study uses descriptive qualitative methods that do not use statistical formulas in the data processing. The qualitative approach places more emphasis on process and 
meaning (Sutopo, 2002, p.38; Lindolf, 1994 p.21). In this qualitative research, there is not much management of numbers.

The data in this study are speech in the form of greetings from the Kerinci community in the village of Jujun, Jambi Province. The data source is from the informant who is a Kerinci community from the village of Jujun, Jambi Province, consisting of one informant. The informant named Zainal Abidin (54). The informants that the researchers chose were native speakers of the Kerinci language in Dasa Jujun.

Data collection techniques using the proficient method by using the basic techniques of fishing and using advanced techniques as proficient at will. The proficient method is a method of collecting data with direct conversations between researchers and informants (Mahsun, 2005, p.93). The basic technique of fishing means in collecting data the researcher provides stimulation (inducement) to the informant, it can be in the form of questions in the interview (Mahsun, 2005, p.94).

The data validation technique that the researchers used in this study were the triangulation technique. In triangulation techniques, researchers will use something else outside the data to check the validity of the data. There are three data triangulation techniques, namely sources, methods, and theories. In this study, researchers will use source triangulation techniques. The researcher will ask one of the Kerinci people in Jujun Village named Usrinawati (46) about the data the researcher collected.

Data analysis techniques used the Intralingual Padan method. Mahsun (2005, p.112) states that the intralingual equivalent method is a method of analysis by connecting the elements that are lingual, both in one language and in several different languages. The researcher will use the intralingual equivalent method to analyze the Kerinci language greeting data in the village of Jujun, Jambi Province.

Then the data will be presented in an informal method. researchers only present data in the form of ordinary words using no special symbols. Mahsun (2005) states that the method of presenting data informally is the formulation using ordinary words, including using technical terminology.

\section{RESULTS AND DISCUSSION}

The research results are divided into three groups, namely: (1) general greetings, (2) custom greetings, and (3) religious greetings.

Common Greeting Words

In the general greeting words, the researcher obtained the greetings of Mamak and Itek to greet the younger siblings of the father and younger siblings of the mother. An example is as follows.

Table 1: Greeting of Mamak and Itek.

\begin{tabular}{|l|l|}
\hline Kerinci Jujun Language & Indonesian \\
\hline Mamak nak gi kanoa? & $\begin{array}{l}\text { Where are you going, } \\
\text { uncle? }\end{array}$ \\
\hline Itek asek apoa? & What auntie cooks? \\
\hline
\end{tabular}

To greet the father's brother or sister's mother, the word Woa is used, both male and female. An example is as follows.

Table 2: Greeting of woa.

\begin{tabular}{|l|l|}
\hline Kerinci Jujun Language & Indonesian \\
\hline Woa bnia laang anak akau. & Uncle makes kites for me. \\
\hline Woa nuhaut ka balie. & $\begin{array}{l}\text { Auntie, I went to the } \\
\text { market. }\end{array}$ \\
\hline
\end{tabular}

In the Kerinci Jujun dialect, the word Kulaut is used to greet boys who are spoiled or loved, while Kanaut is used to greet girls who are spoiled and loved. Examples are as follows.

Table 3: Greeting of woa.

\begin{tabular}{|l|l|}
\hline Kerinci Jujun Language & Indonesian \\
\hline $\begin{array}{l}\text { Eah Kanaut, tbiel nyan } \\
\text { bdo'k. }\end{array}$ & $\begin{array}{l}\text { Hi honey, how thick is your } \\
\text { powder? }\end{array}$ \\
\hline $\begin{array}{l}\text { Kulaut lah udiah mpu } \\
\text { akaan? }\end{array}$ & Honey, have you eaten? \\
\hline
\end{tabular}

In the Kerinci language know the term Apok for men and induk for women. The word greeting is spoken by a child to a mother's brother or sister's father who is not one biological mother and one father.

Table 4: Greetings of woa.

\begin{tabular}{|l|l|}
\hline Kerinci Jujun Language & Indonesian \\
\hline $\begin{array}{l}\text { Aduo uli'ih mancaeng } \\
\text { apok?. }\end{array}$ & $\begin{array}{l}\text { Did you get fish from } \\
\text { Uncle? }\end{array}$ \\
\hline Induk ajia akau karitia & $\begin{array}{l}\text { Auntie, teach me to ride a } \\
\text { bicycle }\end{array}$ \\
\hline
\end{tabular}

Father in the Kerinci Jujun dialect uses the greetings Apiak, and Abak. Meanwhile, mothers use Induok greetings and mak. For greetings, the older sibling is the brother, while the sister is the sister. Whereas younger brothers and sisters are Adiek. An example is as follows.

Tabel 5: Greeting of Apiak, Abak, Induok, and mak.

\begin{tabular}{|l|l|}
\hline Kerinci Jujun Language & Indonesian \\
\hline Abak lah aliek. & dad is home \\
\hline Mak masak apoa? & what do you cook? \\
\hline Abang ajia akau siyiang. & Brother teach me a prayer. \\
\hline $\begin{array}{l}\text { Kakak padiek loa nyo } \\
\text { ngajui. }\end{array}$ & $\begin{array}{l}\text { You are very good at reciting } \\
\text { Qur'an. }\end{array}$ \\
\hline Adiek gi blajia siyiang. & My sister is studying prayer. \\
\hline
\end{tabular}

For greeting words Grandfather, Grandmother, and Ancestor in the Kerinci language, the Jujun dialect uses the greetings Datuk, Nineak, and Nyunyang. Until now the greeting word was still used and did not change to Indonesian. Examples are as follows.

Tabel 6: Greeting of Datuk, Nineak, and Nyunyang.

\begin{tabular}{|ll|l|}
\hline $\begin{array}{l}\text { Kerinci } \\
\text { Language }\end{array}$ & Jujun & Indonesian \\
\hline Aduo & uli' ih $^{\prime}$ & I love grandparents \\
\hline
\end{tabular}




\begin{tabular}{|l|l|}
\hline mancaeng apok?. & \\
\hline $\begin{array}{l}\text { Induk ajia akau } \\
\text { karitia }\end{array}$ & $\begin{array}{l}\text { My ancestral home is near the } \\
\text { volleyball court }\end{array}$ \\
\hline
\end{tabular}

Not Greetings Family

The greeting for people who are older than themselves and under the age of mother and father in the Kerinci Jujun dialect is Awak. The word greeting is still used today. Examples are as follows.

Tabel 7: Greeting of Awak.

\begin{tabular}{|l|l|}
\hline Kerinci Jujun Language & Indonesian \\
Awak suhang lah mna & $\begin{array}{l}\text { You just made this } \\
\text { yourself }\end{array}$ \\
$\begin{array}{l}\text { Awak pandae mna jalien } \\
\text { ka ladiang mamak }\end{array}$ & $\begin{array}{l}\text { Uncle can open the road } \\
\text { to the fields }\end{array}$ \\
\hline
\end{tabular}

In Kerinci, the Jujun dialect knows the word Kayoa as a greeting for parents or is elder and respected. This greeting is generally used by adolescents and adults. Examples are as follows.

Tabel 8: Greeting of Kayoa.

\begin{tabular}{|l|l|}
\hline Kerinci Jujun Language & Indonesian \\
\hline $\begin{array}{l}\text { Kayoa lebih atau dari } \\
\text { pado kamai }\end{array}$ & You know better than us \\
\hline
\end{tabular}

A woman who has a daughter used the word Cik. The word greeting is still used today. Examples are as follows.

Tabel: 9 Greeting of $C i k$.

\begin{tabular}{|l|l|}
\hline Kerinci Jujun Language & Indonesian \\
\hline Cik kanoa? & Where are you going? \\
\hline
\end{tabular}

Greetings for yourself and others

There are many greeting sounds for yourself and others. In the Kerinci Jujun dialect the greeting words for yourself and others are Akau (I),Kaaw (she), Mpaon (he), Nyoa (her), Ikoa (You), Kitoa (us), and Kamai (Us). An example is as follows.

Tabel 10: Kata sapaan akau, kaaw, mpaon, nyoa, ikoa, kitoa, dan kamai

\begin{tabular}{|l|l|}
\hline Kerinci Jujun Language & Indonesian \\
\hline Akau nak gi usiek & I want to play \\
\hline Kaaw piyoa? & What is wrong with you? \\
\hline Mpaon anak kanoa? & Where are you going \\
\hline Nyoa lah padiek & He is already smart \\
\hline Ikoa jatuoh & You fell down \\
\hline Kitoa mnaang & We won \\
\hline Kamai tibuo & We arrived \\
\hline
\end{tabular}

Customary Greetings

In the Kerinci language, the Jujun dialect uses a traditional greeting in accordance with the adat title. These greetings are Pamangku adat, Depati, Ninik Mamak, and Hulubalang. This greeting is not always used in everyday life.
Religious Greetings

In the Kerinci language, the Jujun dialect only knows one religious greeting word, Buya. The word buya has been used from ancient times until now. An example is as follows.

Tabel: 11 Greetings of Buya.

\begin{tabular}{|l|l|}
\hline Kerinci Jujun Language & Indonesian \\
\hline Buya ajia akau tajwuid & $\begin{array}{l}\text { Ustadz taught me a } \\
\text { recitation }\end{array}$ \\
\hline
\end{tabular}

\section{CONCLUSION}

Researchers obtained 32 greetings in the Kerinci Jujun dialect. There are 27 common greeting words, including: Itek, Mamak, Woa, Kanaut, Kulaut, Apok, Mother, Abak, Mak, Apiak, Induok, Brother, Brother, Nineak, Datuk, Ntunyang, Crew, Kayoa, Cik, Akau, Kaaw, Mpaon, Nyoa, Ikoa, Kamai, Kitoa and Nyoa. The traditional greeting words are obtained by four greeting words namely: Pamangku adat, Depati, Ninik Mamak, and Hulubalang. The word greeting religion is obtained or the greeting word, which is Buya.

\section{ACKNOWLEDGMENT}

The researcher is grateful to friends who have encouraged and supported the researcher so that this research article can be completed. Researchers are also grateful to Mr. Zainal Abidin and Mrs. Usrinawati for helping researchers and working with researchers for providing the data that researchers need.

\section{REFERENCES}

[1] Chaer, Abdul. (2000). Tata Bahasa Praktis Bahasa Indonesia. Jakarta: Rineka Cipta.

[2] Lindolf, Thomas R. (1994). Qualitative Communication Research Methods. Thousand Oaks: Sage Publications.

[3] Mafika Sari, Fijri Aulianti. (2016). Kata Sapaan Dalam Cerita Anak Kodomo Ni Naritai Papa To Otona Ni Naritai Boku Karya Haitani Kenjirou. Universitas Dian Nuswantoro: Fakultas Ilmu Budaya.

[4] Mahsun. (2007). Metode Penelitian Bahasa: Tahap, Strategi dan Tekniknya. Jakarta: Raja Grafindo Perseda.

[5] Misnawati. (2017). Kata sapaan bahasa minagkabau. Wacana Etnik Jurnal Ilmu Sosial dan Humaniora. 8(1).

[6] Rusbiyantoro, Wenni. (2011). Penggunaan kata sapaan dalam bahasa melayu kutai. Parole. 2(1).

[7] Sari, Tiara Kartika Maya. (2017). Analisis kata sapaan bahasa melayu subdialek parit senggarang desa sungai ungar utara kecamatan kundur utara kabupaten karimun provinsi kepulawan riau. Universitas Maritim Raja Ali Haji: Artikel EJournal. 
[8] Sugono, Dendy. (2014). Kamus Besar Bahasa Indonesia Pusat Bahasa. Jakarta: GramediaPustaka Utama.

[9] Sutopo, H.B. (2003). metodologi penelitian kualitatif; dasar teori dan terapanya dalam penelitian ilmu-ilmu sosial dan budaya. Surakarta: Universitas Sebelas Maret.

[10] Yule, G. (2006). The Study of Language. UK: Cambridge University Press. 